\begin{tabular}{c} 
International Journal of Engineering \& Technology, $7(3.21)(2018) 250-255$ \\
International Journal of Engineering \& Technology \\
SPC \\
Website: $\frac{\text { www.sciencepubco.com/index.php/IJET }}{\text { Research paper }}$ \\
\hline
\end{tabular}

\title{
Social Capital Strengthening Strategy for Maintaining Investment Sustainability in Lumajang Regency
}

\author{
Zainuri, Sebastiana Viphindrartin ${ }^{1}$, Silvi Asna ${ }^{2}$ \\ ${ }^{1,2}$ Jember University, Indonesia \\ *Corresponding author E-mail: silviasna.unej@gmail.com
}

\begin{abstract}
Lumajang Regency has various potentials to be developed. The geographical condition of the region as one of the potentials should be able to increase the regional income through investments. On the other hand, it has been identified that investment level and regional income have decreased. Based on field research, it is caused by global economic changes (interest, electricity, tax, etc.) and crimes. However, other conditions also exist. For example, there are some investors with no business declining using social capital strength. This study aims to uncover the strategy of social capital strengthening for maintaining investment sustainability in Lumajang Regency. This research employs qualitative phenomenology method. The results of this research indicate that there are two strategies used by investors for maintaining their business in the uncertain condition in Lumajang. First, Personal-Branding Strategy (PBS) is a strategy using personal approach by persuasive ways to create bounding social capital. Meanwhile, Self-Esteem Approach Strategy (SEAS) is a strategy using job competency and power to create linking social capital. This strategy can be used by the existing investors to re-start or maintain their business in Lumajang; it can also become one of considerations of potential investors on what they must do to reach sustainable and profitable business in Lumajang Regency.
\end{abstract}

Keywords: Social capital; Investor; Lumajang Regency

\section{Introduction}

Lumajang Regency is one of administrative areas in East Java Province. Based on the National Socioeconomic Survey 2014, the population of Lumajang district reached 1,026,378 people, consisting of 500,872 men (48.80\%) and 525,506 female (51.20\%). The value of GRDP achieved by Lumajang Regency in the last 5 years shows the supports of economic activities that have been or are being implemented. One of them is investment. As explained by N. Gregory Mankiw in his book Principles of Economics, capital stock is a determinant of economic output that has an important role because changes in capital can change over time and these changes can affect economic growth. The capital stock itself is affected by investment and depreciation. (1) in his book The End of Poverty, states that investment can stop the poverty trap. This investment can increase human capital which is able to make economy more productive to meet basic human needs. It is very clear that investment has a close relationship with GRDP or the level of people's welfare. High and effective investment will certainly increase GRDP, including the community welfare.

Every year the rate of PDRB in Lumajang Regency decreased. Although the decrease is not significant, apparently, this also affects the economy in Lumajang Regency. This decrease was also followed by a decrease of the ratio between investment and GDP of Lumajang Regency 2010-2014. The real GDP figures and the ratio of investment to GRDP show that the economic activities of both communities and governments need to get special attention from both the government and the community. Based on Lumajang Regency (2) report, it is suspected that the cause of the declining GDP figures and the ratio of investment to GRDP is the global economic condition that has not improved; it is also caused by various government policies that are less conducive to the business world such as raising the fuel price (BBM), Basic Electricity Tariff (TDL), and the high interest rate of government bank (BI rate). These aspects are closely related to the high level of crimes. In fact, in steady-state level of capital investment and depreciation action must be balanced. There is no increase or depreciation (3).

Starting investment in Lumajang Regency is actually a proper step in achieving the goals of the organization or business that is making a profit. According to (4) the long-lived company is not only capable of managing tangible assets (land, employees and capital), but also managing intangible assets (people and culture) so that it can become a successful survivor which does not make the company an "economic animal" working only to profit and take the right of the society.

Creating a good relationship with the community for the creation of social capital is not an easy matter. Many special steps and strategies to do, given the pattern and typology of the community of each region are different. The type of business investment developed also affects how the strategy should be applied to create social capital. Therefore, the authors believe that this research is needed in relation to uncover the strategy of strengthening social capital for maintaining the existence of investment in Lumajang District. 


\section{Literature Review}

\subsection{Investment}

Generally, investment means sacrificing the current Indonesian rupiah (IDR) for rupiah in the future. Because it is related to the future, there are 2 (two) attributes inherent in risk and time. Sacrifice happens now and has certainty. New results will be obtained later and the magnitude is uncertain. (5) distinguishes investments into two categories, namely real and financial investments. Real investment in general involves real assets, such as land, machinery, or factories, whereas financial investment involves written contracts, such as ordinary shares and bonds. Financial investment dominates the modern economy, which supports the development of real investment. Real sector is difficult to develop if the financial resources provided by the financial sector are inadequate.

According to (6), investment is defined as expenditures to purchase capital goods and production equipment in order to replace and especially increase the capital goods in the economy that will be used to produce goods and services in the future. In other words, investment means expenditure activities to increase the capacity to produce something in economy. In a different view, investment is an activity of investing both directly and indirectly, with an expectation that in time, the owner of the capital obtains some profit from the investment (7). There are some motivations to buy or invest in a stock, which is profit motive, selling with a higher price in the next period, expecting the return in accordance with the target. In many cases, dividends are also expected by investors. Another motivation is liquidity and security. An important aspect that should be considered with regard to investment in the capital market is the possibility of loss in addition to profit. (8) argues that investment is an overall corporate expense that includes expenditures to purchase raw materials, machineries and equipments, and other capital required in the production process, office building expenses, employee residential buildings and other construction structures, as well as changes in the value of stock or spare items as a result of changes in quantity and price. Investments in macroeconomics can also be distinguished from autonomous investments and induced investments. Autonomous investment is an investment that is not influenced by national income. This means that high national income does not determine the amount of investment made by companies. This type of investment is generally carried out by the government with the intention of being the cornerstone of subsequent economic growth, such as investment for road construction, bridges and other infrastructures. Meanwhile the affected investment is an investment that is influenced by national income. It means that high nationa income will increase people's income and then high income society will increase demands for goods and services. Then, the company's profits will grow and this will encourage more investment.

\subsection{The Types of Investments}

Based on the specificity of activities, investment is divided into six types. (7)

\section{a. New Investment}

New investments are investments for creating new production systems, both as materials of new ventures for new production and production expansion, but they must adopt new production systems.

b. Investment rejuvenation

This type of investment is generally only used to replace old capital goods with new ones, but still with the same production capacity and cost as the tools it replaces.

c. Investment Rationalization

In this group, the old equipment is replaced by a new one but with cheaper production costs, although the capacity is the same as the one it replaces.

d. Investment expansion
In this investment, the new equipment is a replacement for the old one. Capacity is greater while the cost of production is still the same.

e. Modernization Investment

This investment is used to produce new goods that are indeed a new process, or produce old ones with new processes.

f. Diversification Investment

This investment is to extend the production of certain companies, in accordance with the diversification program of the corporate business activities concerned.

(3) divides investment into 3 types: business fixed investment which includes equipments and structures purchased by a company for production; residential investment (residential investment) covering new homes that people buy for residence and landlords purchase for rent; and inventory investment which includes items that a company keeps in store, including materials and supplies, in-process goods and finished goods.

\subsection{Factors that Affect Investment}

Factors influencing investment, according to (9), include:

\section{a. Interest rate}

Interest rates are instrumental in determining the level of investment of a country. If the interest rate is low, then the investment rate will be high because credit from banks is still profitable to invest. On the contrary, the investment of bank credit will be low.

\section{b. Increased economic activity}

Expectation of future economic growth is one determinant factor to make an investment or not. If there is an expectation of an upcoming economic increase in the future, even if the interest rate is greater than the MEC level, the investment may still be made by investors looking at future bigger profits or opportunities in the future.

\section{c. Technology advances}

Technological advances will improve production efficiency and reduce production costs. Thus, technological advances in various economic activities will encourage more investment. The greater the cost required to make a revamp in the technology used, the more investments made. According to (10) investment or capital formation is the main solution for the problem of underdeveloped or developing countries and the key to economic development. This is also confirmed by (11) that the vicious cycle of poverty in the underdeveloped or developing countries can be cut through investment or capital formation.

Three types of factors above are important to investment sustainability, but current condition talk different. Social capital factor also should be considered to boost the investment development. Because interest rate, increased economic activity and technology advanced cannot make the business spared from stealing, social crime and so on. Without social capital, investors must pay the transaction cost higher in long term continually to protect their business existence.

\subsection{The Understanding of Social Capital}

A peaceful and mutually supportive community life is what most people in the world want. However, this will not happen if social relations between communities are not well established. Social capital is an asset created by every individual as the result of good social relationships. The theory of social capital was first found in Pierre Bourdieu's work published in the late 1970s entitled "Le Capital Social: Notes Provisoires". Because the writing is published in French, it does not attract the attention by other scientists, especially social scientists and interested economics. In 1993, (5) 
discussed the same thing and raised the same topic about social capital in English, entitled "Social Capital in the Creation of Human Capital". Then, the writing is published directly into a very interesting discussion for Economics and Social scientists, because social capital brings together two disciplines, Economics and Sociology (12). (13) defines social capital as the appearance of social organizations, such as beliefs, norms, and networks that can improve the efficiency of society by facilitating or cooperating for mutual benefits. Unlike (5) which combines networks and information into one form, Bourdieu as the founder of social capital sees that social networking is not natural, but is shaped through an investment-oriented strategy of institutionalizing group relations that can be used as a source for profitability (12). It can be concluded that there are three major divisions of the concept of social capital as (5) saw, that is social capital as a social relations structure, especially to acquire human capital.

While Bourdieu in (12) focuses more on the ability of social capital in generating economic resources, (14) emphasizes the cooperative relationships that establish democracy through membership of civil groups in (12). Social capital is something that refers to the institutional dimension, the creation of relationship, and the norms that shape the quality and quantity of social relationships in society. Social capital is not just a row of the number of institutions or groups that underpin social life, but a broader spectrum. That is social glue that maintains the unity of group members.

\subsection{Parameters and Indicators of Social Capital}

Social capital is a capital that is cumulative and increases, so that social capital becomes very different from financial capital (14)This social capital will not run out if used. The breakdown or decrease of social capital is mostly due to not being used. Social capital also differs from human capital, because social capital refers to people's ability to associate with others (5). Based on (12) there are three social capital parameters, namely trust, norms and network.

\section{a. Trust}

Social trust is basically a product of good social capital. The existence of good social capital is characterized by the presence of solid social institutions, social capital that creates a harmonious social life (14)

\section{b. Norm}

Norms derived from religion, moral guidance, and secular standards as well as professional codes of ethics. Norms consist of understandings, values, expectations, and goals that are believed and run together by a group of people. However, norms can also be a pre-condition as well as a product of social trust. Norms are constructed and developed based on the history of cooperation in the PBS and applied to support the cooperative climate (14)

\section{c. Network}

Networks facilitate communication and interaction; they also enable the growth of cooperation and trust. (14) argues that close social networks will strengthen the feelings of cooperation of its members and the benefits of its participation. Cooperation is a network of joint ventures between individuals or groups of people to achieve one or more common goals. Almost in all human groups, the pattern of cooperation can be found. Cooperation arises because the individual has an orientation toward the group or against another group.

\section{Methodology}

\subsection{Research Approach}

This study focuses on the social capital strengthening strategy for maintaining investment sustainability in Lumajang Regency using social capital as the unit of analysis. Therefore, qualitative method is the most appropriate research method for the study. This study employs a naturalistic approach in which the researcher collected data using emic perspective based on the view of the research subjects, not the view of the researcher (15). According to (16), qualitative method is used to uncover and understand a phenomenon. Qualitative method can provide details about a complex phenomenon that is difficult to disclose using quantitative method. In qualitative research, as (15) asserts, qualitative researchers do not specify a research based on variables; rather, they consider the social situation of the phenomenon under research. In accordance with phenomenology approach that focuses on the subjective experience of individuals and the world in which they live, this research employs phenomenology as an approach deemed appropriate. Under this approach, the researchers attempt to understand the meaning of events and linkages to people who are in a situation (16).

\subsection{Data Collection Technique}

In data collection, two types of data were collected: primary and secondary data. Primary data is taken directly through observation and interview. Secondary data is taken from some institutions related to this research.

\subsection{Research Location}

The setting of this research is Lumajang Regency. A decreasing investment rate is caused by many factors, which include the increase of interest rate, global economic activities, crimes, and other factors. On the other hand, there are some investors who succeed in maintaining their business without any declining.

\subsection{Data Analysis Technique}

In qualitative research, data analysis was done during data collection and after the collection of data within a certain period. Miles and Huberman (1984) in (15) suggest that activities in qualitative data analysis are carried out continuously until completed, until data saturation is achieved Activities in the data analysis, include: (i) the data collection phase; (ii) the data reduction phase; (iii) the presentation of the data; (iv) verification and conclusion.

\subsection{Data Test Validity}

Data validity test is necessary to convince researchers regarding the conformity of data obtained in the field. (15) mentions that credibility test of data in qualitative research could be done through the extension of observation, improved persistence, triangulation, discussions with colleagues, negative case analysis, and member check. In a study to test the validity of the data using triangulation, (15) states that triangulation is to check data which have been obtained from several different sources. So, data from different sources can answer the phenomena on that occurs in the field.

The sources of triangulation models are considered suitable for the study because informants selected in this study consist of several groups of people who contributed to the implementation of social capital strengthening strategy for maintaining the investment sustainability in Lumajang Regency. To conduct the validity test, concluding statements from different informants were obtained. It is expected that from multiple interviews with several sources, answers to the phenomena that occur in the field can be revealed. 


\section{Results and Findings}

\subsection{Personal-Branding Strategy (PBS)}

(17) mentioned that "social capital is a capital of social relationships which will provide, if necessary, useful 'supports': a capital of honorability and respectability which is often indispensable if one desires to attract clients in socially important positions, and which may serve as currency, for instance in a political career". (17) further stated that "social capital is an attribute of an individual in a social context". One can acquire social capital through purposeful actions and can transform that capital into conventional economic gains. The ability to do so, however, depends on the nature of social obligations, connections, and networks available to the person. Bourdieu's definition above emphasizes social capital and individual roles; the role of social capital exists only within the individual. This definition has not touched the community element. However, in 1992, Bourdieu coined a definition that touches both the individual and the community. (17) proposed the following definition: "social capital is the sum of resources, actual or virtual, that accrue to an individual or a group by virtue of possessing a durable network of more or less institutionalized relationships of mutual acquaintance and recognition"

Personal-branding strategy (PBS) is a strategy to construct social capital using a personal approach by performing useful actions, adopting virtues and establishing harmonious relationships to create strong attachment with the community. PBS is implemented by M Iqbal and Nimin for constructing their self-social capital in order to maintain the sustainability of their investment. Constructing social capital usually through two people or more to achieve mutual objectives (reciprocity). But in this case, $\mathrm{M}$ Iqbal and $\mathrm{Ni}$ min constructed the social capital by their-own self without any collaboration with community as theory stated for their business significance. This strategy cannot be delegated -need tenacious, patient and multi-talent investor to achieve people trust and empathy. PBS creates an "angel" branding figure in the middle of environment who able to help everyone and understand their needs. This strategy will be expensive at the beginning, but it will be cheaper and able to sustain the existence of social capital in the long term.

M Iqbal (informant) is a medium-scale investor in broiler farming. He has been running his business since 1998 until today. His business is an individual business run with his wife. Iqbal's business is located in Dusun Gugot and Dusun Gebang, Krasak Village, Wonorejo-Lumajang Regency. Currently, there are 5 coops containing 35,000 chickens. Each coop is located right in the middle of the local community and some are located on the edge of the village road. So, such effects as unpleasant odor and the appearance of flies are directly felt by the community. The coops are located on the main roadside of Krasak Village. Every citizen who passes along the road can smell the unpleasant odor. Especially during the rainy season, the odor will be stronger. With the position of the coops which are close to the local community, $\mathrm{M}$ Iqbal is required to be able to minimize the adverse effects of his business and make people around the location do not feel harmed by the negative impact of the business. The business run by M Iqbal has undergone various stages before becoming a wellestablished business. Many things happened and became evaluation materials for improvements that must be done.

"Tertatih tatih saya. Jadi terus dari perjalanan waktu saya evaluasi diri saya. Jadinya saya simpulkan bahwa lebih penting pelihara anak kandang daripada ayamnya" ("... It was so hard. So, from time to time, I evaluate myself. I conclude that it is more important to keep the cage keeper than the chicken ") (Source: Interview with M Iqbal, 2016)

Cage keeper is the one who is responsible for keeping the coops and the chickens inside. Each coop contains 7 thousand chickens. Besides keeping the coops safe, the cage keeper is also responsible for cleaning the cage and taking care of chickens. Honesty and responsibility are the key in their duties. Many approaches have been implemented by M Iqbal for controlling his cage keepers. So, the goal of M Iqbal to recruit cage keepers who are honest and responsible can be achieved. These approaches are certainly able to improve the relationship between individuals. According to (5) this relationship structure creates a climate of trust, carries channels of information, and establishes norms. The low structure of relations between individuals will certainly have an impact on the emergence of turmoils in the society such as social jealousy, asymmetric information, crimes, protests, and so forth.

(12) Argues that trust is the expectation that arises in a community that behaves normally, honestly and cooperatively based on norms, for the benefit of members of the community. Deviant behaviors such as theft and burning of cages in the business of M Iqbal are due to dissatisfaction with the behavior of informants so that they becomes uncooperative and dishonest. The informant must lose at least 18 million rupiah (500-800 chickens) in each theft case and must also face the loss of 700 million rupiah when a cage burning happened.

M Iqbal's care to the community becomes one of his strengths, which makes people feel uncomfortable to criticize him. Implicitly, the local people actually have "uneg-uneg" (something untold, but they actually would like to talk about it) over the impact of Iqbal's business. The informant is not only giving chickens to the community, but also rice, school aids water well etc. Similar to his treatment to workers, his business strategy does not only affect his business, but also the welfare of workers which creates high confidence of both the workers and the community. Many good things are done by M Iqbal to strengthen norms and increase trust as well as his network. It is proven that the social capital facilitates his business activities, for example when $\mathrm{M}$ Iqbal needed business licensing, the community approved it by signing an agreement related to the bussines. Nimin, the other informant, also did the same thing. His business is cattle farms. Informants employ PBS strategy to maintain their business to be accepted in the community. Nimin started his business in 1993. He managed the business with his wife. The location of the informant's business was in Dorogowok Village, Kunir sub-district, Lumajang. The informant's business setting is a cow shed just behind the informant's house. This means that the informant business is located in the middle of Dorogowok residence area. The disposal of cow manure that has not been well managed certainly causes unpleasant odor. However, according to the informants, there were no protests or negative things. On the contrary, a neighbor whose house is located just north of Nimin's house said that he was disturbed by the existence of the business. The smell and sounds coming from the farms, according to him, are very disturbing.

As experienced by M Iqbal, reluctance due to good things done by Nimin is able to dampen turnoil in the society. In this case, Nimin also employs residents around his business to graze. Often times, Nimin bought grass from them. In fact, the price of grass per sack purchased from the residents is higher, compared to the fee Nimin has to pay when hiring people to graze. Nimin prefers to buy grass in the neighborhood to build good relations with them. In addition, Nimin also utilizes the "ater-ater" culture to build social capital. "Ater-ater" is the activity of distributing food to neighbors when someone has more food. "Ater-ater" is a cultural activity which aims to acquire social capital. Communication and sharing are parts of the activity. Social jealousy cannot be underestimated, because social jealousy can cause social problems such as crime, fights, quarrels and so on. Thus, in addition to keeping the social attachment and closeness that have been established, "ater-ater" also minimizes the emergence of social jealousy that cannot be predicted. Social trust, including honesty, exemplariness, cooperation, determination and a sense of responsibility towards others, is essential to foster individual virtues that rest on cultural roots (12). These virtues become an accumulation of investments that can be used anytime and anywhere. Nimin states that if "osom" (cow being harvested), he also distributes beef meat to residents. The moment of the holy day is also used by the informant to share, of 
course, to attract public sympathy. In establishing good relations with the community, the wife of the informant, Wiwik, has many roles. Wiwik is a friendly person. She often visits the neighbors just for talking about everything. According to Nimin, that is one of her ways to strengthen her relationship with the local community.

\subsection{Self-Esteem Approach Strategy (SEAS)}

Interaction occurs due to various motives. The ways people interact, communicate, and relate are basically influenced by the desire to achieve common goals that generally are not different from personal goals. Such a situation can occur in long-lasting relationships. This kind of interaction creates social capital, the emotional bond that unites people to achieve common goals, which then creates trust and security from relatively long relationships. As with any financial capital, social capital can be seen as a source that can be used either for current production activities or processes, or reinvested in the future.

Constructing social capital through virtuous activities can be done individually or with the help of others. While PBS does everything to play social capital directly, SEAS (self-esteem approach strategy) is a step taken by informants to maintain the sustainability of its investment through expertise and power. In general, getting close to people through good communication and helping people are the way to construct social capital. But, contrary thing happen in Lumajang. This informan-Subardi Wijaya make the distance with the people to achieve social capital. It is important because of the people's character reason. Most of Lumajang people are from Madura ethnic who have stubborn trait. He believe that through distance and empathy which implicated simultaneously, they will respect and trust him then he able to "control" them become his social capital for his business reason. The informant, Subardi Wijaya, undertook this strategy to build social capital in the community, among workers and partners of PT AUI. In practice, SEAS will generate linking social capital. Linking social capital is a social capital that connects various social groups in different strata Linking social capital links one group or one individual with another individual or group (18).This social capital further describes relationships raised on social class or on the basis of subordinates and superiors. It is rather difficult to imagine how social capital can be formed by two individuals of different economic status. Usually, in terms of the relationships, groups in a higher position obtain more benefits so that the relationships formed tend to be antagonist (18).

Subardi Wijaya or Woei Tuk Puen, or commonly called Pak Embun, is a tobacco entrepreneur in Wonogriyo Village, TekungLumajang Regency. Subardi Wijaya is a Chinese descendant who has run his business since 26 years ago. Wonogriyo Village is an area prone to crime. However, the informant do not feel disturbed by the condition. Because the informant has a high self-esteem of himself. From the above statement, it can be understood that the informant has power in the area. His social capital relationship also reaches the black ball level in Lumajang. This makes the informant feel safe; he does not have to pay more for security costs. Despite the competitors, the informant already feels that there is nothing to worry about with competitors because the informant believes that his business already has strong resilience. The informant is an entrepreneur whose company has become a long-lived company because of his ability to manage intangible and tangible assets. In managing his company, Subardi Wijaya uses the principle of kinship by appointing his partners to be able to interact directly. This is done to facilitate communication with the local community. Building the dependence of the society is also one of the strategies of the informant to strengthen his social linking capital. The availability of labors is the key to successful production. With the dependence of the community, the informant never faces lack of labors to work in the company.

(19) Define social capital as: "a glue that holds societies together with common sense identification, a sense of belonging and shared behavioral norms. This in the coherent helps to define social capital. Without it, society at large will collapse, and there can be no talk of economic growth, environmental sustainability or human well-being." In the implementation of this SEAS, Subardi Wijaya keeps the distance between himself and the community directly in order to create a sense of reluctance in the society to act deviantly. However, because of the distance, the workers have a high degree of loyalty. Subardi Wijaya applies professional principles with a sense of kinship. Subardi Wijaya also gives appreciation to the workers in the form of bonus or even where they can have lunch together. Subardi Wijaya constructed social capital not only within the company and surrounding communities, but also with the company where he sold his tobacco, PT AUI. Based on information from informants, the informants received special treatment from PT AUI due to their reluctance. Subardi Wijaya has strong bargaining in the corporate environment due to his experience. Job competence has facilitated the informants to do the production process. So, this job competence is the aspect which increases the level of self-bargaining of Subardi Wijaya in creating linking social capital through SEAS.

\section{Conclusion}

Investment is an economic activity that become important indicator in area development process. Interest rate, increased economic activity and advanced technology are the indicators which affect the sustainability of investment. But, those three indicators apparently cannot able to protect the business from theft, fraud, social demonstration, social fire and so on that will higher the transaction cost. Furthermore, social capital comes to support those three indicators for maintaining the business. Social capital is a social glue that can help people to achieve the same goals with reciprocity relationship. Giving empathy because of similarity of problem or groups is the key in constructing social capital. But on the other hand, personal-branding strategy (PBS) constructs the social capital without reciprocity relationship and the similarity of problems or groups. This strategy is done by the business leader (cannot be delegated) to do some approaches to society in order to get sympathy and trust as business significance reason. In contrary, selfesteem approach strategy (SEAS) is other strategy which use power, self-confidence and social "distance" to construct social capital. But, behind that distance and self-esteem, the investor has high empathy (indirectly) to help society around his business to achieve strong social capital for maintaining his investment.

\section{Acknowledgements:}

This research work is supported by Jember University

\section{References}

[1] Sachs J. The end of poverty: New York: Penguin; 2005

[2] BPS. Publikasi ICOR Kabupaten Lumajang. In: BPS, editor. Lumajang: BPS Lumajang; 2015. p. 12-4.

[3] Mankiew NG. Makroekonomi. Jakarta: Erlangga; 2006.

[4] De Geus A. The living company: habits for survival in a turbulent environment. London: Nicholas Brealey. 1997.

[5] Coleman JS. Dasar-dasar teori sosial. Bandung: Nusa Media(Translated from James S Colleman Foundation of Social Theority The Belknap Press of Harvard University Press 1994). 2008.

[6] Sukirno S. Pengantar Ekonomi Makro. Jakarta: Raja Grafindo Persada; 2000.

[7] Lincolin A. Ekonomi Pembangunan. Yogyakarta: STIE YKPN; 1999. 120 p.

[8] Deliarnov. Pengantar Ekonomi Makro. Jakarta: UI Press; 1995.

[9] Bodie ZAKdAJM. Investasi. Jakarta: Salemba Empat; 2006. 194 p.

[10] Jhingan M. Ekonomi pembangunan dan perencanaan. Jakarta: Raja Grafindo Persada; 1999. 
[11] Nurkse R. Masalah pembentukan modal di negara-negara yang sedang membangun. Jakarta: Bharata; 1996.

[12] Yustika AE. Ekonomi Kelembagaan: Definisi, Teori, dan Strategi. Malang: Bayumedia Publishing. 2006.

[13] Inayah. Peranan Modal Sosial dalam Pembangunan. Ragam Jurnal Pembangunan Humaniora. 2012;12 No.1.

[14] Putnam RD. The prosperous community. The american prospect. 1993;4(13):35-42.

[15] Sugiyono. Metode Penelitian Kuanitatif Kualitatif dan R\&D. Bandung: Alfabeta; 2008.

[16] Moleong LJ. Metodologi Penelitian Kualitatif Edisi Revisi, Cetakan keduapuluh dua, Bandung: PT. Remaja Rosdakarya Offset. 2006.

[17] Bourdieu P. The forms of capital.(1986). Cultural theory: An anthology. 2011;1.

[18] Woolcock M. Social capital and economic development: Toward a theoretical synthesis and policy framework. Theory and society. 1998;27(2):151-208.

[19] Dasgupta P. Social capital and economic performance: Analytics: Beijer international institute of ecological economics; 2001. 